\title{
Parent Union Liability for Strikes in Breach of Contract
}

\begin{abstract}
A popular local union vice-president is fired for unexcused absences from work. Fellow workers are outraged. They walk off their jobs despite a collective bargaining agreement with the employer that prohibits strikes and offers binding arbitration of grievances.

The wildcat striket shuts down the plant, and the employer urgently requests that the local and international union take steps to end the strike. Local union officers are in fact assisting the strike. The international, however, is not involved, and one of its officers tells strikers that the collective bargaining agreement prohibits such strikes. The international refuses to take more drastic action, however, and as a result the strike drags on for weeks.
\end{abstract}

Strikes in breach of contract sueh as this one plague many industries. Most collective bargaining agreements contain a promise by the union not to strike during the agreement's tern. Unions usually consent to these no-strike clauses in exchange for the employer's promise to arbitrate disputes arising in contract administration. ${ }^{2}$ Each promise is the "quid pro quo" for the other, ${ }^{3}$ because the employer relinquishes some inanagerial autonony in exchange for a period of industrial peace. When strikes in breach of contract occur, einployers have several options: ${ }^{4}$ obtain an mjunction, discharge the strikers, sue for damages, ${ }^{5}$ or simply try to endure the strike.

Section 301 of the Taft-Hartley Act ${ }^{6}$ authorizes dainage suits im federal court for strikes im breach of contract. This Comment discusses the employer's section 301 remedy against the national or international ("parent") union. Examining the legislative history behind section 301, the Coininent finds that Congress imtended to provide employers with

1. A true wildcat stike is one not instigated by officials of the local or international. Some writers use the term "wildcat" to refer to any strike in breach of contract.

2. Textile Workers Union v. Lincoln Mills, 353 U.S. 448, 449, 455 (1957).

3. Boys Markets, Inc. v. Retail Clerks Local 770, 398 U.S. 235, 248 (1970); United Steelworkers v. American Mfg. Co., 363 U.S. 564, 567 (1960).

4. See text accompanying notes $13-20$ and 38-42 infra.

5. A daniage suit unay not be brought if the employer has promised to arbitrate the legality of strikes allegedly in breach of contract. E.g., Bechtel Corp. v. Local 215, Laborers' Int'l Union, 405 F. Supp. 370 (M.D. Pa. 1975), modified on other grounds, 544 F.2d 1207 (3d Cir. 1976). See United Steelworkers v. Warrior \& Gulf Navigation Co., 363 U.S. 574 (1960); United Steelworkers v. American Mfg. Co., 363 U.S. 564 (1960). The employer need not arbitrate, however, unless it has promised to do so. Atkinson v. Sinclair Ref. Co., 370 U.S. 238 (1962).

6. 29 U.S.C. \& 185 (1976). 
an effective damage remedy for such strikes. The Comment then considers why relatively few section 301 suits have been litigated.

One significant obstacle to obtaining damages is the proof that an employer must adduce to imphicate a parent union. The Comment discusses recent federal appellate decisions that adopt a new liability rule requiring the parent union to take affirmative steps to end strikes im breach of contract. This approach, typified by Eazor Express, Inc. $v$. International Brotherhood of Teamsters, ${ }^{7}$ improperly imphies into collective bargaining agreements terms not envisioned by the parties. The Coininent concludes, however, that the principle behind Eazor-that the parent union should not unreasonably sit idle during a strike-has merit. The Coininent therefore proposes a theory of parent union liability that fulfills Congress' purpose by protectimg employer interests without subjecting the union to financial hability for which it did not bargain.

I

\section{CONGRESSIONAL INTENT AND SECTION 301}

Congress enacted the Taft-Hartley $\mathrm{Act}^{8}$ in 1947 over President Truman's veto. In 1946, a wave of strikes had shut down steel mills, coal mines, auto assembly plants, electrical products plants, seaports, and utilities. ${ }^{9}$ Congress and the public believed that umons were too powerful, ${ }^{10}$ that strikes had become too frequent, ${ }^{11}$ and that employers therefore did not receive the industrial peace for which they had bargained. ${ }^{12}$

Weapons at the disposal of employers to prevent or deter strikes in breach of contract generally were then, and are today, meffective. Such strikes are unprotected conduct. Thus, theoretically the employer may discliarge strikers. ${ }^{13}$ Threat of discharge does not deter strikes for several reasons. First, production would be crippled if the employer discharged all employees simultaneously. Second, discharging ouly strike

7. 520 F.2d 951 (3d Cir. 1975), cert. denied, 424 U.S. 935 (1976).

8. 29 U.S.C. \$§ 141-197 (1976).

9. A. Cox, D. Bok, \& R. Gorman, Cases and Materials on labor law 91 (8th ed. 1977).

10. Sce generally id. at 91-93.

11. Sce S. Rep. No. 105, 80th Cong., Ist Sess. 15 (1947) [hereinafter cited as Senate RePORT]; R. GORMAN, Basic TEXT ON LABOR LAW 5 (1976).

12. Textile Workers Union v. Lincoln Mills, 353 U.S. 448, 453-55 (1957); SENATE REPORT, supra note 11, at 16.

13. NLRB v. Sands Mfg. Co., 306 U.S. 332 (1939). A strike is protected, however, if it protests unsafe conditions, Knight Morley Corp., 116 N.L.R.B. 140 (1956), enforced, 251 F.2d 753 (6th Cir. 1957), cert. denied, 357 U.S. 927 (1958), or serious employer unfair labor praetices, Mastro Plastics Corp. v. NLRB, 350 U.S. 270 (1956); Arlan's Dep't Store of Miclngan, Inc., 133 N.L.R.B. 802 (1961) (dictum). 
organizers may be an unfair labor practice if the organizers are union officers. ${ }^{14}$ Third, discharge of strikers may aggravate worker discontent and worsen the strike. ${ }^{15}$ Finally, arbitrators do not always uphold discharges of strikers. ${ }^{16}$

Enjoining a strike in breach of contract is not always possible because of the anti-injunction provisions of the Norris-LaGuardia Act. ${ }^{17}$ The Supreme Court in 1970 held in Boys Markets, Inc. v. Retail Clerks Local $770^{18}$ that strikes over arbitrable issues could be enjomed pending arbitration of the underlying grievance. Boys Markets injunctions, however, are not available in other kinds of strikes ${ }^{19}$ and might not be obeyed in any event. ${ }^{20}$

A powerful damage remedy for strikes therefore was necessary, according to Senator Taft, to inake unions "responsible for their acts."21 Senator Taft explained the state of the law before Taft-Hartley: "[L]abor leaders . . . were reheved from any hability in breaking the contract after they had made the bargam. . . . [S]trikes actually were encouraged and protected . . .".22 $\mathrm{He}$ also observed:

If Unions can break agreements with relative impunity, then [nostrike agreements coupled with binding arbitration] do not tend to stabilize industrial relations. The execution of an agreement does not by itself proinote industrial peace. The chief advantage which an employer can reasonably expect from a collective labor agreement is assurance of uninterrupted operation during the term of the agreement. Without some effective method of assuring freedom from economic warfare for the tern of the agreement, there is little reason why an enployer would desire to sign such a contract. ${ }^{23}$

In section 301 of the Taft-Hartley Act, ${ }^{24}$ therefore, Congress imtended to give enployers an effective daniage reniedy for strikes that breach collective bargaining agreements. That section was designed to

14. Gould Corp., 237 N.L.R.B. No. 124 (Aug. 25, 1978), 99 L.R.R.M. 1059 (1978).

15. See 86 HARV. L. Rev. 447,454 (1972).

16. See Handsaker \& Handsaker, Remedies and Penalties for Wildcat Strikes: How Arbitrators and Federal Courts Have Ruled, 22 CATH. U.L. Rev. 279, 284 (1973).

17. 29 U.S.C. § 104 (1976).

18. 398 U.S. 235 (1970).

19. In Buffalo Forge Co. v. United Steelworkers, 428 U.S. 397 (1976), the Supreme Court held that a sympathy strike could not be enjoined. The Boys Markets theory permits an injunction only pending arbitration of the underlying grievance. Sympathy strikers have no underlying contract interpretation grievance with the einployer, so there is nothing to arbitrate.

20. Compare Old Ben Coal Corp. v. Local 1487, UMW, 457 F.2d 162 (7th Cir. 1972) with Old Ben Coal Corp. v. Local 1487, UMW, 500 F.2d 950, 952 (7th Cir. 1974). See Gould, On Labor Injunctions Pending Arbitration: Recasting Buffalo Forge, 30 STAN. L. REv. 533, 541 \& $n .47$ (1978).

21. 93 Cong. ReC. A3043 (1947) (Senator Ball quoting radio address by Senator Taft).

22. Id. at 7537 (remarks of Senator Taft).

23. SENATE REPORT, supra note 11 , at 16.

24. 29 U.S.C. \& 185 (1976). 
remove the procedural and substantive obstacles that blocked damage suits against unions.

Unions could not be sued as entities at common law. ${ }^{25}$ In many states, therefore, each union member had to be made party to a lawsuit. ${ }^{26}$ This rendered suits all but impossible, because each member had to be served with process. Even where union entities were subject to suit, union assets sometimes could not be reached to satisfy a resulting judgment. ${ }^{27}$

Section $301(d)^{28}$ of the Taft-Hartley Act remedied the service-ofprocess difficulty. Sections $301(a)^{29}$ and (b) $)^{30}$ permitted suit, and recovery, against the union as an entity in federal district court regardless of diversity of citizenship or the amount im controversy.

The Taft-Hartley Act also removed a substantive ${ }^{31}$ difficulty caused by the Norris-LaGuardia Act. Under section 6 of that Act, ${ }^{32}$ no union was hable for damages resultimg from a strike absent "clear proof" of actual participation, authorization, or ratification by the union. ${ }^{33}$ Sections $301(b)^{34}$ and (e) ${ }^{35}$ of Taft-Hartley altered that standard by incorporatimg principles of agency law. ${ }^{36}$ Thus, whether the union as an entity actually authorized or subsequently ratified a strike is not controlling on the issue of union hability. ${ }^{37}$

Despite these procedural and substantive changes, it has become evident that employers still do not have an effective damage remedy for strikes in breach of contract. The remaining sections describe the obstacles to obtaining damages, and suggest how courts should interpret no-strike promises in collective bargaining agreements to provide the effective section 301 damage remedy that Congress envisioned.

25. See Pullman Standard Car Mfg. Co. v. Local 2928, United Steelworkers, 152 F.2d 493 (7th Cir. 1945); Witmer, Trade Union Liability: The Problem of the Unincorporated Corporation, 51 YALE L.J. 40 (1941).

26. SENATE REPORT, supra note 11, at 16.

27. Id. at 17.

28. 29 U.S.C. $\$ 185(d)(1976)$.

29. Id. $\S 185(\mathrm{a})$.

30. Id. $\$ 185(\mathrm{~b})$.

31. See Textile Workers Union v. Lincoln Mills, 353 U.S. 448, 455 (1957).

32. 29 U.S.C. $\$ 106$ (1976).

33. See UMW v. Gibbs, 383 U.S. 715, 735-37 (1966); United Bhd. of Carpenters v. United States, 330 U.S. 395,403 (1947).

34. 29 U.S.C. $\$ 185(b)$ (1976).

35. Id. § $185(\mathrm{e})$.

36. 93 CoNG. REC. 4022, 4435, 6521 (1947) (reinarks of Senator Taft).

37. 29 U.S.C. $\S 185(\mathrm{e})(1976)$. 


\section{Why ARe Few Section 301 Suits Litigated?}

Relatively few damage suits are litigated compared to the number of strikes in breach of collective bargaining agreements. ${ }^{38}$ In part, this can be attributed to employer clioice not to sue for damages. Many suits are deterred, also, through inability to hold the parent union liable.

\section{A. Employer Collective Bargaining Tactics}

Frequently, it is not in the employer's longrun interest to sue a union for damages resulting from a strike. A rational employer may forego a tenable-even a strong-section 301 damage suit im order to preserve harmonious relations with a umion and its officials. A mature collective bargaining relationship is marked by the trust and confidence between labor and management that results from amicable dealing. ${ }^{39}$ Contract negotiation and interpretation flow more smoothly-and thus, less expensively - in such a relationship. Disputes that could lead to work stoppages may be defused more easily when a tradition of cordial dealing has been established.

Post-strike damage suits impair this industrial harmony. ${ }^{40}$ Acrimony developed during a strike may not dissipate if a damage action is pending for months, perhaps years, after the strike ends. Lengthy probing by each side during discovery reinforces umion-management hostility. Future contract negotiation and administration may be harmed. ${ }^{41}$ Additional strikes-both legal and illegal-may result from an einployer's atteinpt to recoup losses caused by a simgle strike.

The employer has an interest in preserving harmony not only with the union entity, but also with umion leadership. Strong union officials normally will be able to quell dissident splinter groups within the union that inight instigate production interruptions. Protracted post-strike damage suits against unions and umion officials may destabilize intraunion political power. Damage suits may be especially counterproductive froin the einployer's viewpoint when the strike at issue was a wildcat strike because the lawsuit exacerbates existing intraunion dissension. Such factionalism harns the employer's interest in stable, moderate union government.

Circumstances sometimes exist, however, that warrant an em-

38. See, e.g., R. Evans, Public Policy Toward Labor I48-49 (I965).

39. See Washington Post, July 17, 1979, § A, at 2, col. I.

40. See Boys Markets, Inc. v. Retail Clerks Local 770, 398 U.S. 235, 248 \& n.17 (1970).

4I. Cf. UAW v. Hoosier Cardinal Corp., 383 U.S. 696, 702-03 (1966) (damage suits normally occur only when the smooth functioning of the consensual collective bargaining process has broken down). 
ployer's suit for damages after a strike. An employer planning to go out of busmess ${ }^{42}$ has no further stake in amicable relations with a union and might seek to recoup damages caused by a strike. Another employer rationally might sue if it beheves that the company is unable to deal with a union effectively because the union regards the company as weak. A post-strike damage suit may bolster a company's stature in the eyes of its employees and the union.

The employer also might sue if it beheves the lawsuit will deter future strikes. Moreover, merely the threat of a lawsuit nnay deter strikes. The employer nay believe that it inust carry out a threat to sue made during a strike to preserve the future deterrent value of such threats.

\section{B. Lack of Assets to Satisfy Judgments}

Some employers do not sue because they are unable to reach a defendant with assets. There usually are three potential defendants in a section 301 suit for a strike in breach of contract: imdividual union inembers, the local union, and the parent union.

Individual union members almost never will be a source of damage recovery. Section 301(b) of the Taft-Hartley Act prevents taking an mdividual member's assets to satisfy a judgment against the umion entity. ${ }^{43}$ That statute does not expressly prevent suing an individual for instigatimg a wildcat strike for which the union is not liable ${ }^{44}$ but the mdividual is unlikely to have adequate assets to satisfy a judgment in any event.

Local unions in many cases also do not have sufficient assets to pay strike damages. Many locals are shoestring operations ${ }^{45}$ without even one full-time staff person. ${ }^{46}$ Many parent umions control the strike fund. ${ }^{47}$ Some parent unions collect dues directly from members and remit to the locals only enough money to continue functioning. ${ }^{48}$

Because it is not likely that a local union or its members have adequate assets to satisfy a strike judgment, einployers who wish to sue

42. See Eazor Express, Inc. v. International Bhd. of Teamsters, 357 F. Supp. 158, 161 n.3 (W.D. Pa. 1973), modified on issue of damages, 520 F.2d 951 (3d Cir. 1975), cert. denied, 424 U.S. 935 (1976) (one of the Eazor plaintiffs never resumed operations after the strike for which it sued).

43. 29 U.S.C. \& 185(b) (1976); Atkinson v. Sinclair Ref. Co., 370 U.S. 238 (1962).

44. One appellate court has held that individual union members are not liable under $\S 301$ even when the strike is one for which the union is not liable. Sinclair Oil Corp. v. Oil, Chem. \& Atomic Workers Int'l Union, 452 F.2d 49 (7th Cir. 1971).

45. See Stein, Union Finance and LMRDA, in Regulating UnION Government 140-41 (M. Estey, P. Taft, \& M. Wagner eds. 1964).

46. See D. BoK \& J. Dunlop, Labor and the American Community 148, 154 (1970).

47. See, e.g., M. Rothbaum, The Government of the OiL, Chemical and Atomic WORKERS UNION 147 (1962).

48. See, e.g., L. Ulman, The Government of The Steel Workers' Union 15-21 (1962). 
therefore often look to the parent union for satisfaction. Generally, these suits are successful only when the parent is a signatory to the collective bargaining agreement. ${ }^{49}$

49. Umion custom normally determines which union entities will sign a collective bargaining agreenient. Frequently only the local union is a party; sometimes only the parent is a party; other times, both parent and local unions are parties. The usual rule is that a parent that is not a signatory cannot be liable to the employer for a strike in breach of contract because the parent has not promised the employer anything. E.g., Califormia Trucking Ass'n v. Teaunsters Local 70, 86 L.R.R.M. 2643 (N.D. Cal. 1974); Owens v. International Ass'n of Heat \& Frost Insulators, 60 L.R.R.M. 2143 (D. Nev. 1965). Sone exceptions to this rule exist. A parent has been held liable, even though it is not a signatory to the agreement, because it was closely involved with the negotiation of the agreenuent:

In a technical sense, the International's [denial that it had been a party to the contracts] is unassailable. It was not a signatory to the agreement: rather its "National Conımittee" was. The imquiry, then, must be into the relationship between the National Committee, the signatory to the agreements, and the International.

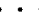

Notwithstanding the formalities surrounding its creation, the National Committee is intimately associated with the Interuational. At all relevant times its nieinbers were appointed by the president of the International pursuant to authorization froin the Executive Board: many of its members were contemporaneous menibers of the International's Executive Board; it was chaired by the president of the International; its funding was controlled by the International; and the International conducts the ratification vote its constitution requires after a national accord with its members' einployers is reached. The National Committee has no status or shape as a labor organization independent of the International. It has no constitution or by-laws, and files no reports with the Department of Labor as it would be required to do if it were a labor organization. In short, it is organizationally and functionally an admimistrative arm of the International. Its sole purpose, to achieve national negotiations and national agreements, furthers the aims of the Interuational. While it may act, in terms of the sophistries, on behalf of the local umions, in terms of the realities, it acts on behalf of the International. . . [T] herefore, ... the International, through its National Committee, is a party to the labor agreements.

Eazor Express, Inc. v. International Bhd. of Teamsters, 357 F. Supp. 158, 167-68 (W.D. Pa. 1973) (footnote omitted), modified on issue of damages, 520 F.2d 951 (3d Cir. 1975), cert. denied, 424 U.S. 935 (1976).

Similarly, another parent union was held hable where only the local was a signatory, because the parent exercised significant control over the local's affairs. New England Tel. \& Tel. Co. v. International Bhd. of Electrical Workers, 384 F. Supp. 752 (D. Mass. 1974).

Expansion of liability to a nonsignatory cntity might appear to be an inappropriate invasion of freedom of contract. See NLRB v. Burns Int'I Security Servs., Inc., 406 U.S. 272, 287 (1972); H.K. Porter Co. v. NLRB, 397 U.S. 99, 108 (1970); United Steclworkers v. American Mfg. Co., 363 U.S. 564, 570 (1960) (Breiman, J., concurring). In other contexts, however, courts have extended collective bargaining rights and obligations to nonsignatory parties. John Wiley \& Sons, Inc. v. Livimgston, 376 U.S. 543 (1964) (a noncontracting successor einployer may be bound by a contract negotiated by the predecessor einployer). A "collective bargaining agreeinent is not an ordinary contract," id. at 550, so ordinary primciples of contract law on the issue of parties to the contract do not necessarily apply. Thus, numerous cases have found a local to be a party to a contract signed only by a parent. See, e.g., Blake Constr. Co. v. Laborers' Int'1 Union, 511 F.2d 324 (D.C. Cir. I975); Operating Eng'rs Local 653 v. Bay City Erection Co., 300 F.2d 270 (5th Cir. 1962); Local 6I1, Hotel, Restaurant Employees \& Bartenders Union v. Harry M. Stevens, Inc., 89 L.R.R.M. 2016 (S.D.N.Y. 1975). Contra, Local 12405, UMW v. Martin Marietta Corp., 328 F.2d 945 (7th Cir.), cert. denied, 379 U.S. 880 (1964). Also, an employer unay be bound by a contract signed by a subsidiary, even though the parent was not a signatory, where the parent had extensive control over the subsidiary. UAW v. Cardwell Mfg. Co., 416 F. Supp. 1267 (D. Kan. 1976). By analogy, it may be legitimate to bind a parent union to a contract signed only by its local where 


\section{The Proof Burden: Inability to Prove Parent Union Involvement}

Effective damage recovery often occurs only when the employer successfully sues the parent union. The traditional theory of liability, however, makes recovery against the parent union difficult.

United Construction Workers v. Haislip Baking Co. ${ }^{50}$ states the traditional rule. In that case, officials of the parent union advised wildcat strikers to return to work but did nothing else to help terminate the strike. ${ }^{51}$ The employer argued that the parent union should have taken vigorous action to get employees back to work. The Court of Appeals for the Fourth Circuit rejected that argument. The parent umon, the court held, need not take affirmative steps to end a strike as long as it does not adopt, encourage, or prolong the strike. ${ }^{52}$

Explicit authorization or ratification by the parent union, even if it exists, normally cannot be proven. Often it does not exist, because a union that wishes to encourage strikers can do so without stating its purpose.

Suppose that a sympathy strike occurs in violation of a collective bargaining agreement that contains a no-strike clause and the common provision:

Should any employee or group of employees strike during this contract's term, the International Union or Local Union agree upon notification by the company to direct such employee or group of employees to resume work.

After dealing unsuccessfully with local union leaders, the company requests the international to notify the members to return to work. Suppose further that the parent union wants to encourage the sympathy strike $^{53}$ in order to mamtam good relations with the other union. The parent union obviously does not want to mcur financial liability for the sympathy strike. It niglit, while performing its contractual obhgation

circumstances indicate that the parent is deeply involved in the negotiation of the agreement, Eazor Express, Inc. v. International Bhd. of Teamsters, 357 F. Supp. at 167-68, or in the conduct of the local's affairs, New England Tel. \& Tel. Co. v. International Bhd. of Electrical Workers, 384 F. Supp. 752 (D. Mass. 1974).

In any event, the conclusions of this paper should apply at least where the parent is a signatory to the contract. Even where the parent is a party, however, it may contractually limit its liability for strikes. E.g., Reising's Sunrise Bakery, Inc. v. Bakery \& Confectionary Workers Local 35, 94 L.R.R.M. 2262 (E.D. La. 1976) (contractual agreement eliminating union liability for a syinpathy strike). See also Ransdell v. International Ass'n of Machinists, 97 L.R.R.M. 2738 (E.D. Wis. 1978) (damage suit dismissed because employer agreed not to sue in exchange for the workers returning to their jobs).

50. 223 F.2d 872 (4th Cir.), cert. denied, 350 U.S. 847 (1955).

51. Id. at 877 .

52. Id. at $877-78$.

53. This illustration is not intended to suggest that the parent union usually wishes to support a local's strike in breach of contract. A parent union might oppose a strike but still not wish to intervene. See notes $100-08$ and accompanying text infra. 
to direct the strikers to return to work, take steps to undermine the effect of doing so. ${ }^{54}$ Before officially notifying strikers that they must return to work, the parent union might send the following letter to meinbers:

\section{Dear Union Member:}

Our collective bargaining agreement with the company prohibits strikes. Upon the company's request we will, of course, comply with the contract by officially advising you not to strike. 55

As a result, members may not believe that the umon actually wants einployees to return to work even when the "official" letter is sent. The parent union can provide ineinbers with an additional clue to disregard the letter by placing its text in quotation marks, ${ }^{56}$ or by sending it over the signature of a low-level official or an official that never deals with the striking local. ${ }^{57}$

Courts liave long recognized that subtle clues such as these can instigate or prolong a strike. An historic mineworkers' strike proinpted one court to observe: "if a nod or a wink or a code was used in place of the word 'strike,' there was just as much a strike called as if the word 'strike' liad been used." 58

The "nod or wink" is not always obvious. Employers usually cannot slow that the parent umion-which frequently is the only financially responsible party-authorized or ratified the strike. Recognizing sucir obstacles to the effective damage remedy that Congress intended, several courts have adopted new liability theories that lielp the employer surmount the proof burden.

\section{III}

\section{Alternative Liability Theories}

Courts have articulated at least two new contract $^{59}$ liability theo-

54. The following union tactics are suggested by plaintiff's allegations in Owens-Illinois, Inc. v. Local 29, Glass Bottle Blowers Ass'n, No. CV 77-3545-MML (C.D. Cal., filed Sept. 22, 1977).

55. Cf. Plamtiff's Memorandun1 of Contentions of Fact and Law at 19-20 in id. (local union).

56. Cf. id. at $20-21$.

57. $C f$. id. at 21.

58. United States v. UMW, 77 F. Supp. 563, 566 (D.D.C. 1948), affd, 177 F.2d 29 (D.C. Cir.), cert. denied, 338 U.S. 871 (1949). See also United Textile Workers Local 120 v. Newberry Mills, Inc., 238 F. Supp. 366, 372-73 (W.D.S.C. 1965).

59. Modern cases against a parent or local for strikes in breach of contract are litigated under a contract theory. Since in many cases the parent is the only party with significant assets, see text acconupanying notes $43-48$ supra, and since the parent often is not a party to the contract, see note 49 supra, a tort theory might be invoked against the parent.

Consider a parent that abets a strike in breach of contract. If only the local is party to the contract, a plaintiff employer might sue the parent for the tort of intentional interference witlit the einployer's contract with the local. Judge Rubin may have hinted this in dictum in Reising's 
ries that ease the employer's burden of proving that a parent union breached a no-strike promise.

\section{A. "Mass Action"}

When hundreds of individuals virtually simultaneously walk off a job, it is unrealistic to believe that each acted independently. Large numbers of workers do not act collectively without leadership. ${ }^{60}$ Several courts therefore have imposed liability on the union by reasoning that the union inust have provided that leadership. ${ }^{61}$

The "inass action" theory possibly justifies local union liability because of the close contact between local officials and workers. It does not follow, however, that parent union participation in the strike can reasonably be inferred. Many parent unions oversee thousands of locals $^{62}$ and seldom deal closely with any one local. ${ }^{63}$ To attribute strike imstigation to parent unions is therefore unsound and unfair. ${ }^{64}$ Cases $^{65}$ imposing liability on parent unions ${ }^{66}$ based on the "mass action" theory seem incorrectly decided.

Sunrise Bakery, Inc. v. Bakery \& Confectionary Workers Local 35, 94 L.R.R.M. 2262 (E.D. La. 1976).

In general, the elements of the tort of intentional interference with contract appear to be that one party caused another to breach a contract by an intentional, affirmative action. See generally Developments in the Law - Competitive Torts, 77 HARv. L. Rev. 888, 960 (1964). Even if these requirements are met, however, no recovery can be had if the action is privileged. Id. A privilege exists if the breaching party, and the party inducing the breach, are in a relationship that demands "free communication," id. at 966-67, without fear of tort liability. A parent union probably is privileged from tort hability if it induces a local to breach its collective bargaining contract, because the parent is in this type of "confidential relationship" with its local. See Imperial Ice Co.v. Rossier, 18 Cal. 2d 33, 35, 112 P.2d 631, 632 (1941) (dictuin); Lawless v. Brotherhood of Painters, Decorators \& Paperhangers, 143 Cal. App. 2d 474, 478, 300 P.2d 159, 162 (2d Dist. 1956).

It is anomalous that the tort theory founders on the close "confidential relationship" between parent and local, because it is the very fact that the entities are legally distinct that prevents the parent froin being contractually bound when only the local is a signatory to the contract, see note 49 supra.

60. United States v. UMW, 77 F. Supp. 563, 566 (D.D.C. 1948), affd, 177 F.2d 29 (D.C. Cir.), cert. denied, 338 U.S. 871 (1949).

61. E.g., Eazor Express, Inc. v. International Bhd. of Teamsters, 520 F.2d 95I, 963 (3d Cir. 1975), cert. denied, 424 U.S. 935 (1976).

62. See, e.g., M. Horowitz, The Structure and Government of the Carpenters' UNION 4 (1962).

63. See D. BoK \& J. Dunlop, supra note 46 , at 152.

64. See Carbon Fuel Co. v. UMW, 582 F.2d 1346, 1349 (4th Cir. 1978), eert. granted on another issue, 99 S. Ct. 1495 (1979); United States Steel Corp. v. UMW, 534 F.2d 1063, 1074 (3d Cir. 1976).

65. E.g., Eazor Express, Inc. v. International Bhd. of Teamsters, 520 F.2d 951, 963 (3d Cir. 1975) (alternative holding), cert. denied, 424 U.S. 935 (1976).

66. This Comment discusses theories of parent union liability. Whether a local appropriately nay be held liable under the mass action theory is beyond the scope of this Comment. 


\section{B. The Duty to Use "All Reasonable Means" to End a Strike}

Several courts have held a parent union hable for a strike that it did not instigate if that union failed to use all reasonable means to terminate the strike once it had begun. Before analyzimg this theory, this Comment will examme the powers over local unions that a parent union inay have at its disposal.

\section{Scope of Parent Union Authority Over Its Locals}

Statutes authorize a parent union-if its constitution so permitsto impose a trusteeship on a local union, or fine, suspend or otherwise discipline local union inembers, to prevent strikes in violation of collective bargaining agreenuents. The parent union also may have at its disposal additional nechanisins to induce a local to cease striking.

\section{a. Trusteeships}

The parent union may find that the officers of a striking local are unable or unwilling to require nueinbers to return to work. ${ }^{67}$ Under certain circumstances the parent inay impose a trusteeship on the local union by stripping local officers of their authority and vesting it in a person chosen by the parent.

Trusteeships sonvetimes may be effective in endimg strikes. ${ }^{68}$ Control over local union offices gives the trustee control over telephones, copying inachines, the local union newspaper, inembership files, and other instruments that are necessary to operate an effective strike. Section 302 of the Labor-Manageinent Reporting and Disclosure Act ${ }^{69}$ permits trusteeships over locals to ensure, inter alia, "the performance of collective bargaining agreeinents"-i.e., no-strike clauses. Trusteeships established in accordance with the union's constitution and bylaws" will be "presuned vahd" for eighteen nıonths and are not subject to attack except upon "clear and convincing proof" that the (1971).

67. See, e.g., Jolly v. Gorman, 428 F. 2d 960, 963 (5th Cir. 1970), cert. denied, 400 U.S. 1023

68. "“[T]rusteeships'. . . are among the most effective devices which responsible international officers have to insure order within their organization." S. REP. No. 187, 86th Cong., 1st Sess. 17, reprinted in [1959] U.S. CODE CONG. \& AD. NEws 2318, 2333.

69. 29 U.S.C. $\$ 462$ (1976) provides:

Trusteeships shall be established and administered by a labor organization over a subordinate body only in accordance with the constitution and bylaws of the organization which has assumed trusteeship over the subordinate body and for the purpose of correcting corruption or financial malpractice, assuring the performance of collective bargaining agreeinents or other duties of a bargaining representative, restoring democratic procedures, or otherwise carrying out the legitimate objects of such labor organization.

70. See id. See also Miller v. Laborers' Int'1 Umion, 96 L.R.R.M. 3289 (D.D.C. 1977); Electrical Workers Local 1186 v. Eli, 307 F. Supp. 495 (D. Hawaii 1969). 
trusteeship was mamtained for an illegitimate purpose. ${ }^{71}$ Courts therefore will exercise only limited review of a decision to trustee a local. ${ }^{72}$

The Court of Appeals for the Fiftli Circuit applied these general principles in Jolly $v$. Gorman. ${ }^{73}$ The local union in that case struck a plant of the Masonite Corporation in apparent violation of a no-strike clause. Parent union leadership repeatedly demanded that members return to work, but the local union for several months refused. The parent union therefore trusteed the local to end the illegal strike. The court of appeals noted that it was "obvious" that the imternational had the power to trustee the local for that purpose, ${ }^{74}$ and therefore sustained the trusteeship.

Other cases have reached similar results. ${ }^{75}$

\section{b. Discipline}

Many union constitutions permit the parent union to discipline its members for acts violating that constitution. ${ }^{76}$ Commonly listed as grounds for discipline are actions tending to impair a union's contractual obligations, ${ }^{77}$ such as no-strike clauses. A union therefore inay

71. 29 U.S.C. $\$ 464$ (c) (1976) provides:

In any proceeding pursuant to this section a trusteeship establislied by a labor organization in conformity with the procedural requirenents of its constitution and bylaws and authorized or ratified after a fair liearing either before the executive board or before sucli other body as may be provided in accordance with its constitution or bylaws sliall be presumed valid for a period of eighteen months from the date of its establishment and shall not be subject to attack during such period except upon clear and convincing proof that the trusteeship was not established or inaintained in good faith for a purpose allowable under section 462 of this title. After the expiration of eighteen months the trusteeship shall be presumed invalid in any suclı proceeding and its discontinuance sliall be decreed unless the labor organization sliall slow by clear and convincing proof that the continuation of the trusteeship is necessary for a purpose allowable under section 462 of this title. In the latter event the court inay dismiss the complaint or retain jurisdiction of the cause on such conditions and for sucl period as it deems appropriate.

72. See Gordon v. Laborers' Int'l Union, 490 F.2d 133 (10th Cir. 1973), cert. denied, 419 U.S. 836 (1974); Executive Bd. Local 1302, United Blid. of Carpenters v. United Bhd. of Carpenters, 477 F.2d 612 (2d Cir. 1973); Bailey v. Dixon, 314 F. Supp. 452 (E.D. La. 1970), affd, 451 F.2d 160 (5th Cir. 1971), cert. denied, 406 U.S. 945 (1971). But cf. Benda v. Grand Lodge of Int'1 Ass'n of Machinists, 584 F.2d 308 (9th Cir. 1978) (preliminary injunction agaimst trusteeship permissible despite statutory presumption of validity where local union establisles some probability of success on the inerits and that irreparable harn would result from the trusteeship), cert. denied, 99 S. Ct. 2065 (1979).

73. 428 F.2d 960 (5th Cir. 1970), cert. denied, 400 U.S. 1023 (1971).

74. Id. at 965 , quoting Summers, Legal Limitations on Union Discipline, 64 HARv. L. Rev. 1049,1065 (1951).

75. National Ass'n of Letter Carriers v. Sombrotto, 449 F.2d 915 (2d Cir. 1971); Local 238, Laborers' Int'l Union v. Fosco, 80 L.R.R.M. 2081 (E.D. Wash. 1972); Electrical Workers Local 1186 v. Eli, 307 F. Supp. 495 (D. Hawaii 1969).

76. Burke v. Interuational Blid. of Boilernakers, 302 F. Supp. 1345 (N.D. Cal. 1967), affd per curiam, 417 F.2d 1063 (9th Cir. 1969).

77. A typical union constitution might prohibit, inter alia:

failure to exercise responsibility toward the Interuational Brotherlood as an institution 
fine, suspend, ${ }^{78}$ or even expel ${ }^{79}$ a member for leadimg an illegal strike. A court in reviewing discipline ${ }^{80}$ will examine whether procedural due process requirenents were observed, ${ }^{81}$ but will not substitute its judgment on the inerits for that of the union tribunal. ${ }^{82}$

\section{c. Strike Benefits}

Where the parent union controls a strike fund, locals striking in breach of contract inay be denied access to it. ${ }^{83}$

\section{d. Creative Intervention}

Creative intervention by the parent union may help cool local hostilities during the wildcat strike. Consider a coinpany's arguably wrongful suspension of an employee. A wildcat strike over that issue probably would be subject to a Boys Markets injunction, ${ }^{84}$ but the injunction might not be obeyed. One union confronted with a strike over this issue persuaded workers to return to their jobs by paying the suspended member's salary during the arbitration of the grievance. ${ }^{85}$

or engaging in conduct which would interfere with the International Brotherhood's per-

formance of its obligations.

Constitution of the International Brotherhood of Boilermakers, art. XVII, $\S \mathrm{I}(I)$, quoted in id. at I350-5I.

78. Cf. Falcone v. Dantinne, 288 F. Supp. 719 (E.D. Pa. 1968) (suspension of inember by local union), rev'd on other grounds, 420 F.2d I157 (3d Cir. I969).

79. See Pearl v. Tarantola, 36I F. Supp. 288 (S.D.N.Y. 1973) (expulsion would have been upheId if it had been based explicitly on the member's instigation of illegal strike; in instant case, expulsion illegal because record showed that expulsion might have been for a different, illegitimate reason).

80. See Packer v. International Bhd. of Teamsters Local 249, 428 F. Supp. 145 (W.D. Pa. I977) (court will not enjoin intraunion disciplinary process invoked against alleged advocate of a strike in breach of contract).

8I. 29 U.S.C. \& $4 \mathrm{II}(\mathrm{a})(5)$ (I976) provides:

No inember of any labor organization may be fined, suspended, expelled, or otherwise disciplined except for nonpayinent of dues by such organization or by any officer thereof unless such inember has been (A) served with written specific charges; (B) given a reasonable time to prepare his defense; (C) afforded a full and fair hearing.

See Falcone v. Dantinne, 420 F.2d 1 I57 (3d Cir. I969), rev'g 288 F. Supp. 719 (E.D. Pa. 1968). See also International Bhd. of Boilermakers v. Hardeman, 401 U.S. 233 (1971).

82. See, e.g., Reyes v. Laborers Local 16, 464 F.2d 595 (I0th Cir. 1972), cert. denied, 411 U.S. 9 I5 (1973); Burke v. International Bhd. of Boilermakers, 302 F. Supp. 1345 (N.D. Cal. 1967), affd per curiam, 417 F.2d 1063 (9th Cir. I969).

83. See L. UlmaN, supra note 48 , at 20.

84. Boys Markets, Inc. v. Retail Clerks Local 770, 398 U.S. 235 (1970). See text accompanying note 18 supra.

85. Penn Packing Co. v. Meat Cutters Local 195, 497 F.2d 888, 890 (3d Cir. 1974) (local union action). It might, of course, be bad union policy to establish a precedent of giving relief to grieving workers before arbitration. 


\section{e. Parent Union's Use of Intervention Powers}

While union constitutions vary, ${ }^{86}$ many permit a parent union to use the aforementioned powers to ensure comphance with a no-strike clause in a collective bargaining agreement. Other than those cited above, however, few cases involve parent union intervention. The lack of decisions does not reflect doubt about the legahity of trusteeships or discipline to prevent illegal strikes. ${ }^{87}$ Few cases exist simply because the parent union - absent a legal obhigation to take affirmative steps to end a strike - has httle incentive to do so. Thus, although a parent union legally may act to terminate an illegal strike, it does not follow that it must do so.

\section{The Eazor Rule}

Several courts recently have demanded that the parent union, as part of its obligation to fulfill the terms of the collective bargaining agreement, use its influence with, and authority over, a local umon to terminate a strike in breach of contract.

In Eazor Express, Inc. v. International Brotherhood of Teamsters, ${ }^{88}$ the Court of Appeals for the Third Circuit held an interuational umion liable for failing to use all reasonable means to get striking members back to work. In Eazor, trucking firms were struck by union members who complained that two employees had been discharged unjustifiably. The strikes violated the collective bargaining agreement, which barred strikes until all contractual means of settlement had been exhausted. The union locals and the international disavowed the strikes and urged inembers to return to work, but neither the local nor the international took more drastic action. The district judge found that union officials did not instigate or conduct the strike. The court nevertheless held both parent and local liable for failing to use all reasonable means to terminate the strike. The unions were held liable for all the employer's damages suffered after the first two days of the five-week walkout. ${ }^{89}$ The court of appeals increased the damage award to more than one million dollars $^{90}$ and affirmed.

In finding the parent union liable ${ }^{91}$ for a strike which it neither

86. For a description of how a union constitution limits the pareut's ability to discipline its members, see Dolly Madison Indus., Inc., 74-1 Lab. Arb. Awards 78092 (1974) (E. Archer, Arb.).

87. "It is so obvious that a union may punish its members for engaging in an unauthorized strike that the courts lave never bothered to discuss the matter." Summers, Legal Limitations on Union Discipline, 64 HaRv. L. REv. 1049, 1065 (1951).

88. 520 F.2d 951 (3d Cir. 1975), cert. denied, 424 U.S. 935 (1976).

89. Id. at $965-66$.

90. Id. at $971-74$.

91. The parent union did not sign the contract, but it was held liable anyway. See note 49 supra. 
called nor aided, the court held that imphed in the no-strike clause was a promise to use all reasonable means to end a strike. The court cited legislative history of section $301^{92}$ showing that Congress mtended to ensure that employers who had agreed to arbitrate contract grievances in exchange for the union's promise not to strike would receive the industrial peace for which they bargamed. The court said it would be "illusory" for the parent union to promise not to strike, ${ }^{93}$ and then to sit by idly when an unauthorized walkout occurred. ${ }^{94}$ The court noted that the parent union had many powers available to it, such as trusteeship, discipline, or commanding a secret ballot strike vote, that might have halted the uprising. Failure to use them breached the term that the court imphed in the contract.

The Eazor principle of hability ${ }^{95}$ seems responsive to Congress' wish to give enuployers an effective section 301 damage remedy. ${ }^{96}$ The new principle articulated in Eazor, however, has three flaws.

First, implying a term of this significance into a collective bargaining agreement mupairs the well-estabhshed labor law principle of freedoni of contract. ${ }^{97}$ If the parties had intended to make the parent union

92. See notes 8-37 and accompanying text supra.

93. The parent union was found implicitly to have promised not to strike beeause it was so closely involved in contract negotiations. See note 49 supra.

94. 520 F.2d at $959-60$.

95. The Third Circuit has continued to apply the Eazor principle in recent cases. Thus, a parent union must use all reasonable means to stop certam strikes even where the collective bargainimg agreement does not contain an express no-strike clause; the duty to use all reasonable means will be imphed from the existence of binding grievance arbitration. United States Steel Corp. v. UMW, 534 F.2d 1063 (3d Cir. 1976). The court will not, however, imply a promise not to engage in sympathy strikes from the existence of bimding grievance arbitration, because a sympathy strike normally does not arise out of a contract grievance. United States Steel Corp. v. UMW, 548 F.2d 67 (3d Cir. 1976), cert. denied, 431 U.S. 968 (1977). The parent does have an Eazor duty to use all reasonable ineans to stop a sympathy strike resulting from a primary strike in breach of contract, where the primary strike involves the parent and steuns from a dispute subject to arbitration. Republic Steel Corp. v. UMW, 570 F.2d 467 (3d Cir. 1978).

Other courts also have adopted the Eazor principle of liabihity. Wagner Elec. Corp. v. Loeal 1104, Int'l Union of Electrical Workers, 496 F.2d 954 (8th Cir. 1974); California Trucking Ass'n v. Teamsters Local 70, 94 L.R.R.M. 2981 (N.D. Cal. 1977).

Still other courts reject Eazor. Carbon Fuel Co. v. UMW, 582 F.2d 1346 (4th Cir. 1978), cert. granted, 99 S. Ct. 1495 (1979); Southern Ohio Coal Co. v. UMW, 551 F.2d 695 (6th Cir.), cert. denied, 434 U.S. 876 (1977); Peabody Coal Co. v. Local 1734, UMW, 543 F.2d 10 (6th Cir. 1976), cert. denied, 430 U.S. 940 (1977).

96. See notes 8-37 and accompanying text supra. The Supreine Court in UMW v. Gibbs, 383 U.S. 715, 739 (1966), noted that "[t] here can be no rigid requirement that a union affirmatively disavow such unlawful acts as may previously have oceurred." This statement, however, was made in interpreting $\S 6$ of the Norris-LaGuardia Act, 29 U.S.C. $\$ 106$ (1976), whieh contains a higher standard of proof than that of $\$ 301$. See notes 31-37 and accompanying text supra. In fact, Congress intended in $\S 301$ specifically to reduce the Norris-LaGuardia standard. Id. The Gibbs dictum therefore is mapplicable in $\$ 301$ suits.

97. See NLRB v. Burns Int'l Security Servs., Inc., 406 U.S. 272, 287 (1972); H.K. Porter Co. v. NLRB, 397 U.S. 99, 108 (1970). In the seminal "steelworker trilogy," one Justice wrote: "The parties are free to nuake that promise as broad or as narrow as they wish, for there is no coinpul- 
liable for unreasonable inaction alone, they could have so specified in the contract. The Eazor court, in an overly technical reading of the Teamsters contract, ignored the clear intention of the parties that the parent union not be hiable for nonfeasance. ${ }^{98}$

The second flaw in Eazor is the speed with which the union was required to act before liability accrued. Courts cannot expect a parent union to intervene with potent weapons such as discipline or trusteeship two days after a walkout begins. In one case im which a parent union did intervene, a trusteeship was imposed only after a strike had contimued for seven months. ${ }^{99}$

Third, the Eazor court held that the parent, in deciding what steps to take to end the strike, was not entitled to consider the intraunion political effect of its actions. ${ }^{100}$ This makes no sense, because imposing severe sanctions solnetimes is counterproductive both in the short and the long run. Untimely parent intervention may make a strike longer rather than shorter. Intervention may prompt a wider insurrection, because true wildcat strikes represent rebellion against the union hierarchy as well as against the enuployer. ${ }^{101}$ When the parent takes what appears to be a "pro-management" stance in trying to end a strike, its influence with strikers may diminish. ${ }^{102}$ Thus, a legal rule forcing the parent in all cases to use "the politics of power" 103 may destroy the parent's ability to use the pohitics of persuasion.

Long term harm may result even if parent intervention is effective in ending a particular strike, because imprudent use of the parent's most potent weapons can reduce their effectiveness in the future. ${ }^{104}$ For exainple, excessive imterference by the imternational union might

sion in law requiring them to include any such promises in their agreement." United Steelworkers v. American Mfg. Co., 363 U.S. 564, 570 (1960) (Brennan, J., concurring).

98. The Third Circuit disregarded two clauses that purported to absolve the parent of liability. The court held that one exculpatory clause pertained only to strikes instituted by unauthorized acts of job stewards. 520 F.2d at 961 . The other exculpatory clause exphicitly said that the union would not be liable for strikes resulting from "unauthorized acts of its inembers." Id. The court held that this limitation did not apply because the union was being held hable not for the actions of its members, but for the union's own neglect in failing to take affirmative steps to end the strike. Id. at 961-62. This surely distorts the intent of the parties and terms should not be implied in contracts where the bargaining history suggests a contrary intention.

99. Jolly v. Gorman, 428 F.2d 960, 963 (5th Cir. 1970), cert. denied, 400 U.S. 1023 (1971).

100. 520 F.2d at 967.

101. See Gould, The Status of Unauthorized and "Wildcat" Strikes under the National Labor Relations Act, 52 CORNell L.Q. 672, 701-02 (1967); 89 HARv. L. Rev. 601, 608 (1976).

102. See Dolly Madison Indus., Inc., 74-1 Lab. Arb. Awards \ 8092 (1974) (E. Archer, Arb.); Whitnan, Wildcat Strikes: The Unions' Narrowing Path to Rectitude?, 50 IND. L.J. 472, 481-82 (1975).

103. Eazor Express, Inc. v. International Bhd. of Teamsters, 357 F. Supp. 158, 167 (W.D. Pa. 1973), modifed on issue of damages, 520 F.2d 951 (3d Cir. 1975), cert. denied, 424 U.S. 935 (1976).

104. See D. BoK \& J. DunLop, supra note 46, at 178. See also Seidman, Emergence of Concern with Union Government and Administration, in REgulating UNION GOVERNMENT 17 (M. 
even provoke the local to disaffiliate with the parent. The relationship between a local and an international is a voluntary one, so the local usually is free to withdraw. ${ }^{105}$

These undesirable consequences are not merely matters of intraunion concern. They also threaten the employer, because disputes within a union may impair effective collective bargaining. ${ }^{106}$ A good union manages discontent; that is, union leaders act as a moderatimg force on recalcitrant members. Thus, an employer generally prefers to deal with union leaders who are supported by their members. Manageinent cannot bargam effectively if union officials cannot trade off concessions and still be able to guarantee membership approval ${ }^{107}$ of a tentative accord.

It is not realistic im every case, moreover, to think of the parent union as an entity with absolute control over its locals and members. The parent not only does not have control over locals and members; im inany cases it cannot even count on their loyalty. ${ }^{108}$

The Eazor court inexplicably rejected the aforementioned contentions. It is therefore difficult to comprehend what the court ineant when it mandated the use of all reasonable means to end strikes. "All reasonable" means inust be those that a reasonable union leader would use under the circumstances. ${ }^{109}$ That suggests that the parent union official should weigh the benefit of a particular type of intervention against its harm. The Eazor court, lowever, seemed to want unions to use all possible ineans to end strikes, not all reasonable means. ${ }^{10}$ This seems to be an incorrect interpretation of the contract, because no union would promise to take steps that would jeopardize its viability.

Estey, P. Taft, \& M. Wagner eds. 1964); Soffer, Collective Bargaining and Federal Regulation of Union Government, in id. at 112-13; Gould, supra note 101, at 672.

105. For example, in the 1960 's locals split from the International Brotherhood of Pulp, Sulphite \& Paper Mill Workers to form the Association of Western Pulp \& Paper Workers. For cases demonstrating the failure of the old international to thwart local disaffiliations, see Phillips v. Osborne, 403 F.2d 826 (9th Cir. 1968); International Bhd. of Pulp, Sulphite \& Paper Mill Workers v. Delaney, 73 Wasl. 2d 956, 442 P.2d 250 (1968).

106. See Part IIA supra.

107. See N.Y. Times, Aug. 6, 1976, § D, at 5, col. 1.

108. See Gould, The Status of Unauthorizcd and "Wildcat" Strikes Under the National Labor Relations Act, 52 CORNELL L.Q. 672, 701 (1967).

109. Cf. Restatement (SECOND) OF TORTS $\$ 283$, Comment e (1965); id. $\$ 291$, Comment d (to determine if conduct is reasonable, one must weigh the value of the conduct against its risks).

110. The Eazor court defined "reasonable" means to be those "within the power of the unions to employ and . . . likely to be effective to end the strikes." 520 F.2d at 967. That description is not consistent with the normal legal definition of "reasonable." Consider an automobile driver on an uncrowded highway. We would not say that the driver was unreasonable in traveling at 50 miles per lrour even though, conccdedly, the likelihood of accident would be reduced if the driver instead traveled at 35 miles per hour. The union leader, by analogy, is not necessarily acting unreasonably in failing to use all possible steps to end a strike if the risks exceed the probable benefit. 
Thus, the Eazor court should have permitted the union to weigh costs and benefits in the manner suggested in the preceding paragraphs.

IV

Proper Application of the “All Reasonable Means" PRINCIPLE

The preceding discussion established that the Eazor approach is flawed. The principle that parent unions should take reasonable affirmative steps to end strikes nevertheless lias merit. This section suggests that the proper application of that principle is to impose liability only where the parent acted unreasonably and where union members inferred support for the strike from that inaction.

\section{A. The No-Strike Clause}

The enployer has bargained away some nanagerial autonomy in exchange for the parent union's no-strike promise. ${ }^{11}$ With that promise, the parent does not guarantee that unauthorized strikes will not occur. ${ }^{112}$ The promise does, however, bind the parent not to contribute to a walkout. The parent may be perceived as supporting a walkout both when it acts affirmatively to assist the strike and when it fails to act at all. To understand why this is so, it is necessary to consider a strike from a striker's perspective.

\section{B. The Importance of Rank-and-File Members' Perception of the Parent Union}

That a union fails to take all reasonable steps to end a strike alone does not justify innplying a contractual agreement to pay damages. ${ }^{113}$ The significance of parental inaction varies from the strikers' point of view. An essential elentent of the inquiry, therefore, is whether the strikers imterpret the parent's failure to intervene to be encouragement.

Although most participants in a strike in breach of contract are aware that they are breaching their contract, they probably do not understand conipletely the possible legal or practical consequences of their actions. For exanuple, inanagement nnay have threatened to fire

111. The parent usually will not be contractually liable unless it is a party to the contract. See note 49 supra.

112. Penn Packing Co. v. Meat Cutters Local 195, 497 F.2d 888, 890 (3d Cir. 1974). The nostrike clause has two functions: it is a promise by the union and it establishes a rule of conduct for employees. See Feller, A General Theory of the Collective Bargaining Agreement, 61 CALIF. L. REv. 663, 797 (1973). The employer's lawsuit is based not on the members' breach of their rule of conduct, but on the union's alleged breach of its promise not to conduct, encourage, or induce the strike. Id.

113. See notes $97-110$ and accoinpanying text supra. 
the strikers. Strikers may be unsure whether management can or is likely to carry out such a threat. Rank-and-file members, and even inexperienced local officials, therefore may be influenced by parent union officials. ${ }^{114}$

When the parent union does not use the powers it has under its constitution to terminate the walkout, inembers may believe they discern at least tacit support for the strike. They may even interpret inaction to be "studied ambivalence"115 meant to be a signal116 mdicating authorization. This is particularly true where the parent in the past has taken an active role in the local's affairs ${ }^{17}$ because maction by the parent is extraordinary in that situation, and hence particularly susceptible to the inference of support. Failure to take reasonable affirmative action is inconsistent with the union's contractual obligation not to sanction walkouts if strikers infer sanction from unexercised power. ${ }^{118}$

\section{The Importance of Parent Union's Determination of Costs and Benefits of Intervention}

This analysis does not imply that a parent umion must intervene when its officials reasonably believe that a wildcat strike will be brief, or that intervention by the parent will aggravate the dispute or destroy intraunion discipline and harmony. ${ }^{119}$ The parent's no-strike promise ineans only that the parent is liable when it unreasonably fails to intervene. Thus, for example, the parent will not be liable under this theory for failing to trustee a local if the parent reasonably believes that such action would provoke the local to disaffiliate. Under these circumstances, parent union inaction is not unreasonable. Similarly, where a strike lias been underway only for a few days and seems likely to end soon, the parent reasonably might decide not to expel a strike leader froin ineinbership because the benefit to the employer of that action ending a short strike - was too small to risk corrosion of the international's long run influence with the local and its leaders. Nor, of course, will the parent be liable for not taking affirmative action to end a strike if the union constitution does not empower it $^{120}$ to take that action.

114. See Plaintiff's Memorandum of Contentions of Fact and Law at 24, Owens-Illinois, Inc. v. Local 29, Glass Bottle Blowers Ass'n, No. CV 77-3545-MML (C.D. Cal., filed Scpt. 22, 1977).

115. Southern Ohio Coal Co. v. UMW, 551 F.2d 695, 701 (6th Cir.), cert. denied, 434 U.S. 876 (1977).

116. See notes 54-58 and accompanying text supra.

117. See Oxco Brush Div., Vistron Corp. v. International Ass'n of Machimists, 93 L.R.R.M. 2721 (M.D. Tenn. 1974), affd, 538 F.2d 329 (6th Cir. I976), cert. denied, 429 U.S. 1072 (1977).

118. Celotex Corp. v. United Steelworkers, 388 F. Supp. 1132 (E.D. Pa. 1974).

119. See notes 100-05 and accompanying text supra.

120. See note 86 and accompanying text supra. 
On the other hand, where risk to the union is relatively slight and harm to the employer great, a court applying this standard will hold the parent liable for failing to take reasonable ${ }^{121}$ steps within its power. The parent therefore breaches its no-strike promise if, when strikers look to the parent for reinforcenient, it responds witl unreasonable equivocal inaction ${ }^{122}$ and thereby abets the strike.

\section{Consequences of Considering Parent Reasonableness and Strikers' Inference of Support}

The suggested approach, which would impose liability only where the parent acted unreasonably and where the members from that inferred support for the strike, ${ }^{123}$ is preferable to either the Haislip ${ }^{124}$ or Eazor ${ }^{125}$ rules. This analysis recognizes that local unions and meinbers may interpret the parent union's unreasonable failure to intervene as

121. A measnre to end a strike is reasonable if the harm to the employer of the strike, discounted by the probability that the measure will not be effective, exceeds the harm of the union of intervening with that nieasure. See notes 100-10 supra.

122. See Noranda Aluminnm, lnc. v. United Bhd. of Carpenters, 382 F. Supp. 1258 (E.D. Mo. 1973) (secondary boycott suit under 29 U.S.C. \$ 187 (1976)), affd, 528 F.2d 1304 (8th Cir. 1976).

123. In practice, the employer must prove that the umion had legal authority under its constitution and federal labor laws to help end the strike. The employer also must prove that strikers inferred support fron imaction. The latter could be proved in two ways. First, strikers might so testify. Second, the factinder could infer from objective evidence that strikers inferred support from inaction. The kinds of objective evidence that the employer conld produce include, inter alia. (1) that the parent usually took an active role in day-to-day affairs of the local but did not mtervene in the strike; (2) that the parent in the past had intervened in strikes, but did not imtervene in the instant strike; (3) that the parent paid strike benefits in the instant strike; (4) that the parent gave a "nod or wink" to strikers that suggested support for the strike, see text accompanying note 58 supra, (5) that the strike had gone on so loug that the parent necessarily would have knowledge of it, and of the harm to the employer; or (6) that the strike was violent, therefore deniandimg parent attention.

The burden of producing evidence then would shift to the defendant as is done under the doctrine of res ipsa loquitur in torts, in situations where the facts are peculiarly within the knowledge of that party. See generally 65A C.J.S. Negligence $\$ 220.7$ (1966). The burden of proof, however, would remam with the employer once the union had prodnced evidence on the issue.

Using objective evidence to prove that the strikers inferred support from parent inaction need not be exceptionally difficult. For example, the Court of Appeals for the Eighth Circuit recently upheld a trial court finding that picketers imferred support from union "surface neutrality." Pickens-Bond Constr. Co. v. United Bhd. of Carpenters Local 690, 586 F.2d 1234, 1240-41 (8th Cir. 1978) (local union as defendant) (secondary boycott picketing).

124. United Constr. Workers v. Haislip Baking Co., 223 F.2d 872 (4th Cir.), cert. denied, 350 U.S. 847 (1955).

125. 520 F.2d 951 (3d Cir. 1975), cert. denied, 424 U.S. 935 (1976).

This analysis presumes a simple no-strike promise such as the following:

There sluall be no strike or work stoppage of any nature by the parent union or local umion dnring the term of this contract.

If the employer and parent agree that the parent should not be liable in damages for failing to take steps to end a strike, the parties should append the appropriate limitation language to the nostrike clause. Absent suclı a provision, the no-strike promise necessarily imphes a promise by the union not to abet a strike tacitly by unreasonable inaction. 
support for a strike. The no-strike clause bargamed for by the employer is meaningless if the parent, through unreasonable inaction, conveys implied authorization of a strike. ${ }^{126}$ Unlike Eazor, however, the approach suggested by this Comment does not distort the no-strike promise to require something that the parent never would promise: to take action that would endanger the parent's existence or unreasonably danıge its relations with local unions.

\section{CONCLUSION}

Congress wanted to create an effective damage remedy for strikes in breach of contract when it passed section 301 of the Taft-Hartley Act. Recovery against parent unions often is necessary to fulfill Congress' intent, but it is difficult to prove exphicit strike authorization by the parent. Union members may infer that the parent authorized a strike unless the parent takes affirmative action to end the strike. A parent union therefore should be liable when it unreasonably fails to intervene to end a strike, and where strikers from this inaction inferred sanction, encouragement, or support.

Paul W. Cane, Jr.*

126. See Republic Steel Corp. v. UMW, 570 F.2d 467 (3d Cir. 1978):

The International union simply must bear certain obligations if it is to continue to be entitled to the rights and benefits accorded by our national labor policy. To the extent that any union ... refuses to enforce appropriately authorized union discipline upon recalcitrant meinbers who violate . . . collective bargaining agreeinents . . that union can be said to liave abrogated a proportion of valued rights granted to the union under our national labor policy. ...

... We do not believe it is asking too much that the International fulfill . . its own responsibility to umpire, adjust, adjudicate, and settle, and where necessary, to impose sanctions upon those members who wilfully repudiate the obligations under the contract . . . .

Id. at 479-80 (footnote omitted).

* A.B. 1976, Dartmouth College; J.D. 1979, Boalt Hall School of Law, University of California, Berkeley; Law Clerk 1979-80, The Honorable Carl McGowan, United States Court of Appeals for the District of Columbia Circuit.. 